叶有华,林珊玉,何玉琳,王丹丹,陈晓意,倪广艳.粤港澳大湾区海岸带生态系统修复框架.生态学报, 2021,41(23):9186-9195.

Ye Y H, Lin S Y, He Y L, Wang D D, Chen X Y, Ni G Y.Restoration framework of coastal ecosystems in the Guangdong-Hong Kong-Macao Greater Bay Area.Acta Ecologica Sinica, 2021,41(23):9186-9195.

\title{
粤港澳大湾区海岸带生态系统修复框架
}

\author{
叶有华 ${ }^{1,2}$, 林珊玉 ${ }^{1}$, 何玉琳 ${ }^{2}$, 王丹丹 ${ }^{2}{ }^{*}$, 陈晓意 ${ }^{2}$, 倪广艳 ${ }^{3}$ \\ 1 仲恺农业工程学院 园艺园林学院, 广州 510225 \\ 2 深圳中大环保科技创新工程中心有限公司, 深圳 518001 \\ 3 中国科学院退化生态系统植被恢复与管理重点实验室, 中国科学院华南植物园, 广州 510650
}

摘要: 粤港澳大湾区是全球四大湾区之一,也是我国重要的战略发展区,具有极强的开放性、经济性、生态性、社会性、海洋性和 系统性特征,具有重要的理论和实践研究价值。海岸带生态系统是粤港澳大湾区重要的生态系统类型之一。受快速城市化的 影响, 粤港澳大湾区海岸带生态系统存在诸多问题,这些问题已成为影响陆海生态安全的重要因素。海岸带生态系统修复是国 土空间生态修复的重要组成部分之一。为加快促进粤港澳大湾区海岸带修复,在分析粤港澳大湾区海岸带主要类型与特征基 础上,通过剖析其现状海岸带生态修复存在的主要问题,依托山水林田湖草海生命共同体和陆海统筹等系统理念, 提出粤港澳 大湾区海岸带生态系统修复框架设计思路。基于粤港澳大湾区海岸带生态系统受植被、湿地、水文地质、人类活动、经济发展水 平、产业发展特征、香港和澳门特别行政区等影响因素, 构建了粤港澳大湾区海岸带生态系统分区、分类、分级修复框架,形成了 由珠三角核心区、粤港澳大湾区、珠三角滨海城市群、珠江流域构成的粤港澳大湾区“一核一区一群一流域”海岸带生态系统修 复新格局。在此基础上提出了粤港澳大湾区海岸带生态系统修复“十条”。以流域作为生态修复治理的基本单元,将影响海岸 带生态系统平衡的多种因素进行分类整理,从生态系统整体性和流域系统性出发,坚持水陆联动、陆海统筹,实施以水为核心的 山水林田湖草海一体化修复,从而实现粤港澳大湾区海岸带生态系统修复新目标。通过优化湾区海岸带生态环境,维护湾区海 岸带生态平衡, 提高湾区海岸带生态安全格局,进而促进粤港澳大湾区的可持续发展和生态文明建设。

关键词 : 粤港澳大湾区;海岸带生态系统;生态修复

\section{Restoration framework of coastal ecosystems in the Guangdong-Hong Kong- Macao Greater Bay Area}

\footnotetext{
YE Youhua ${ }^{1,2}$, LIN Shanyu ${ }^{1}$, HE Yulin ${ }^{2}$, WANG Dandan ${ }^{2, *}$, CHEN Xiaoyi ${ }^{2}$, NI Guangyan ${ }^{3}$

1 College of Horticulture and Landscape Architecture, Zhongkai University of Agricultural Engineering, Guangzhou 510225, China

2 Shenzhen Zhongda Environmental Protection Science and Technology Innovation Engineering Center Limited Liability Company, Shenzhen 518001, China

3 Key Laboratory of Degraded Ecosystem and Vegetation Restoration, Chinese Academy of Sciences, South China Botanical Garden, Chinese Academy of Sciences, Guangzhou 510650, China
}

\begin{abstract}
The Guangdong-Hong Kong-Macao Greater Bay Area (GBA) is one of four major bay areas in the world, and it is an important strategic development area in China. The GBA has strong open, economic, ecological, social, oceanic and systemic characteristics with important research value. The coastal ecosystem is one of the most important ecosystem types in the GBA. Affected by rapid urbanization, there are many problems in the coastal ecosystem of the GBA. These problems have affected the ecological security of land and sea. Besides, coastal ecosystem restoration is one of the important components of the ecological restoration of territory and space. To promote the restoration of the GBA, this paper puts

基金项目:2019 年仲恺青年学者科研启动资金项目 (KA180581314); 广东省科技计划项目 (2019B121202001); 海南省生态修复专项资金 ( HNZY2020-033)

收稿日期: 2020-05-01; 采用日期: 2021-05-08

*通讯作者 Corresponding author.E-mail: 18727255851@163.com
\end{abstract}


forward the design idea for the restoration of the coastal ecosystems in the GBA. The idea is based on analysis of the main types and characteristics of the coastal zone in the GBA, by analyzing the main problems in the ecological restoration of the current coastal zone, and relying on the system concepts of a community of landscapes, forests, fields, lakes, grasses ( sea) and of the coordination of land and sea. Based on the influence of vegetation, wetlands, hydrogeology, human activities, economic development level, industrial development characteristics, and Hong Kong and Macao Special Administrative Regions on the coastal ecosystem of the GBA, the coastal ecosystem zoning, classification and hierarchical restoration planning framework of the GBA is constructed. A new pattern of the coastal ecological zone in the GBA is composed of the core area of the Pearl River Delta, the GBA, the Pearl River Delta Coastal City Group, and the Pearl River Basin. Under this new pattern, the "ten measures” of the coastal ecosystem restoration plan in the GBA are proposed. Taking watershed as the basic unit of ecological restoration and governance, the various factors that affect the balance of coastal ecosystems are classified and sorted out. This will start from the integrity of the ecosystem and the system of the watershed, by insisting on water-land linkage and land-sea coordination. Then, the integrated restoration of the landscape, forest, field, lake and grass ( sea) with water as the core is implemented, so as to realize the new goals of the coastal ecosystem restoration plan of the GBA. Moreover, through the optimization of the coastal ecological environment and the maintenance of the ecological balance of the coastal zone in the GBA, the coastal ecological security pattern of the GBA can be improved. Further, the sustainable development and ecological civilization construction of the GBA will be promoted.

Key Words : Guangdong-Hong Kong-Macao Greater Bay Area; coastal zone ecosystem; ecological restoration

2019 年 2 月中共中央国务院印发了《粤港澳大湾区发展规划纲要》 ( 以下简称《纲要》 $)^{[1]}$ 。根据《纲要》, 粤港澳大湾区包括香港、澳门和广东省广州、深圳、珠海、佛山、惠州、东莞、中山、江门、肇庆等珠三角九市, 总 面积 5.6 万 $\mathrm{km}^{2[2]}$ 。粤港澳大湾区是继美国纽约湾区、旧金山湾区和日本东京湾区之后的世界第四大湾 区 $^{[3]}$, 在国家发展大局中具有重要战略地位, 具有极强的开放性、经济性、生态性、社会性、海洋性和系统性特 征,具有重要的理论和实践研究价值。

海岸带生态系统是粤港澳大湾区重要的生态系统类型之一。因受陆地环境、海洋环境、自然条件与人类 活动的多重作用, 海岸带是一个复杂且敏感的生态系统 ${ }^{[4-6]}$, 既具有重要的经济社会效益, 也具有重要的生态 价值。海岸带是人类社会繁荣发展极具潜力和活力的地区, 当前的海岸带生态系统是人类高度集聚、城市群 形成、经济社会高速发展的区域。在粤港澳大湾区,滨海城市承载了其 $83 \%$ 的人口和 $89 \%$ 的 GDP。

由于土地开发利用、海水养殖、污水排放、物种人侵等人为因素, 以及全球气候变化、台风灾害、海平面上 升等自然因素影响 ${ }^{[7-9]}$, 粤港澳大湾区海岸带生态系统正面临着巨大压力, 存在土地资源过度开发、自然岸线 保有率下降、生物多样性减少、海滨湿地丧失、近海水域富营养化、渔业资源退化、海上污染事件频发、污染治 理难度大、防灾减灾压力较大、生态修复参差不齐、保值增值能力有限等一系列问题, 严重危及整个区域的生 态环境安全和经济社会可持续发展 ${ }^{[10-12]}$ 。这些问题已成为陆海生态安全的重要影响因素, 解决与否及其解 决成效必将对粤港澳大湾区生态安全及其整体水平提升产生极其深远的影响。

为此, 《纲要》明确提出要 “加强海岸线保护与管控, 强化近岸海域生态系统保护与修复”。为推动粤港澳 大湾区可持续发展, 非常有必要对其开展修复研究。以修复框架作为粤港澳大湾区海岸带生态系统修复研究 的出发点, 以期通过探索为粤港澳大湾区海岸带生态系统修复建设提供参考。

\section{1 粤港澳大湾区海岸带基本特征}

\section{1 粤港澳大湾区海岸带类型与特征分析}

海岸带为海岸线向内陆延伸 $10 \mathrm{~km}$ 左右, 向海洋延至水深 10- $15 \mathrm{~m}$ 等深线处; 在河口地区, 向内陆延伸至 潮区界, 向海洋延至浑水线或淡水舌 ${ }^{[13-14]}$ 。基于 2015 年广东省第 2 次全国土地调查所用的遥感数据和地理 
地形资料及《中国海域海岛标准名录》,粤港澳大湾区内城市群共拥有大陆和岛屿海岸线 $3201 \mathrm{~km}$ (不计香港 和澳门 $)^{[15]}$ 。粤港澳大湾区各市海岸带现状如表 1 所示, 大陆岸线中基岩海岸线长度为 $374.37 \mathrm{~km}$ 、沙砾质海 岸线长度为 $155.99 \mathrm{~km}$ 、淤泥质海岸线长度为 $10.55 \mathrm{~km}$ 、生物海岸线长度为 $58.85 \mathrm{~km}$ 、人工海岸线长度为 $912.42 \mathrm{~km}^{[16]}$ 。

表 1 粤港澳大湾区各市海岸带现状

Table 1 Present status of coastal zones in the Guangdong-Hong Kong-Macao Greater Bay Area

\begin{tabular}{|c|c|c|c|c|c|c|c|c|}
\hline \multirow{2}{*}{$\begin{array}{l}\text { 城市 } \\
\text { City }\end{array}$} & \multirow{2}{*}{$\begin{array}{c}\text { 大陆海岸* } \\
\text { Mainland coast/km }\end{array}$} & \multirow{2}{*}{$\begin{array}{l}\text { 海岛* } \\
\text { Island/个 }\end{array}$} & \multicolumn{5}{|c|}{ 海岸带类型 * Types of coastal zones } & \multirow{2}{*}{$\begin{array}{c}\text { 红楖林面积* } \\
\text { Area of mangrove } \\
\text { forests } / \mathrm{hm}^{2}\end{array}$} \\
\hline & & & $\mathrm{RC} / \mathrm{km}$ & $\mathrm{SGC} / \mathrm{km}$ & $\mathrm{SC} / \mathrm{km}$ & $\mathrm{BC} / \mathrm{km}$ & $\mathrm{AC} / \mathrm{km}$ & \\
\hline 广州 & 196.51 & 14 & 39.64 & 7.24 & - & 3.49 & 146.14 & 252.23 \\
\hline 深圳 & 316.19 & 51 & 82.84 & 40.75 & - & 28.36 & 164.24 & 499.51 \\
\hline 珠海 & 283.53 & 261 & 58.15 & 18.43 & - & 3.37 & 203.58 & 910.32 \\
\hline 中山 & 55.69 & 5 & 0.66 & - & 7.1 & - & 47.93 & 127.74 \\
\hline 东莞 & 118.55 & 5 & 7.41 & - & - & 16.88 & 94.26 & 126.59 \\
\hline 惠州 & 265.93 & 162 & 71.63 & 78.88 & 2.56 & - & 112.86 & 1064.98 \\
\hline 江门 & 275.78 & 351 & 114.04 & 10.69 & 0.89 & 6.75 & 143.41 & 593.63 \\
\hline 香港 & 1200 (岛) & $\sim 261$ & - & - & - & - & - & 510 \\
\hline 澳门 & 76.7 (岛) & - & 5.37 & 2.3 & - & 7.06 & 61.97 & 1 \\
\hline
\end{tabular}

$\mathrm{RC}$ : 基岩海岸 Rocky coast; SGC:沙砾质海岸 Sand gravel coast; SC: 淤泥质海岸 Silt coast; BC: 生物海岸 Biological coast; AC: 人工海岸 Artificial coast; * 相关数据 来源于《中国海域海岛标准名录》和 2015 年广东省第 2 次全国土地调查所用的遥感数据和地理地形资料

如图 1 所示, 粤港澳大湾区人工海岸线约占大陆岸线总长度的 $60 \%$, 占比最大; 基岩海岸约占大陆岸线总 长度的 $25 \%$; 沙砾质海岸约占大陆岸线总长度的 $10 \%$; 生物海岸约占大陆海岸线总长度的 $4 \%$; 淤泥质海岸约 占大陆岸线总长度的 $1 \%$ 。

如图 1 所示, 在粤港澳大湾区各沿海城市中, 深圳市海岸线最长, 长度为 $316.19 \mathrm{~km}$, 其次是珠海、江门、惠 州, 海岸带长度分别为 $283.53 \mathrm{~km} 、 275.78 \mathrm{~km} 、 265.93 \mathrm{~km}$ 。由于粤港澳大湾区各沿海地区岸线开发利用强度差 异较大, 进而导致各市岸线类型和结构、自然岸线保有率差异较大;广州、深圳、珠海、惠州、东莞、中山和江门 市各市大陆自然岸线保有率分别为 $4.71 \% 、 42.40 \% 、 11.63 \% 、 44.24 \% 、 5.14 \% 、 3.51 \%$ 和 $49.06 \%$ 。粤港澳大湾区 生物海岸主要包含红树林海岸和珊瑚礁海岸, 珠江口岸段以基岩海岸为主 ${ }^{[17]}$ 。

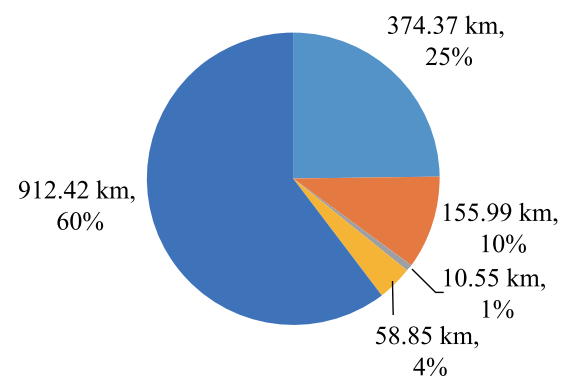

基岩海岸 沙砾质海岸 淤泥质海岸 生物海岸 人工海岸

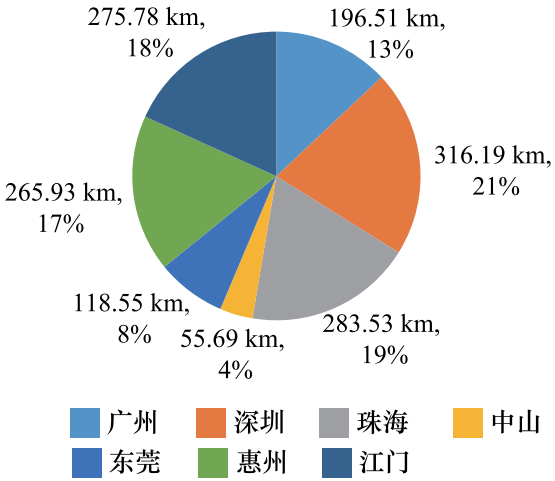

图 1 粤港澳大湾区海岸带类型、长度及占比

Fig.1 Types, length and proportion of coastal zones in the Guangdong-Hong Kong-Macao Greater Bay Area

\section{2 粤港澳大湾区海岸带存在的问题}

粤港澳大湾区海岸带生态系统正面临着巨大的压力 ${ }^{[18-20]}$,并出现一系列严重的生态环境问题。粤港澳 大湾区海岸带存在的主要问题包括以下四个方面:一是粤港澳大湾区中多个沿海城市自然岸线保有率下降, 
1980-2015 年期间, 粤港澳大湾区自然岸线减少 $289.62 \mathrm{~km}$, 自然岸线保有率下降 $18.71 \%$ 。 ${ }^{[21]}$ 。二是近岸海域 环境遭到破坏, 随着大湾区沿岸经济开发的迅猛发展, 大量含氮、磷污水排人海中,近海水体出现了富营养化; 再者由于进行过度的海水养殖,近岸水质不断恶化, 赤潮等富营养化现象频 ${ }^{[22-24]}$ 。三是滨海湿地面积整体 减少, 随着全球气候变暖的不断加剧, 海平面上升速率加速, 近岸海洋动力增强, 海岸侵蚀会进一步加剧, 海水 浸没, 以及海岸带开发利用、湿地围垦建设等人类干扰行为,造成滨海湿地 (滩涂) 的损失及典型海洋生境面 积的减小 ${ }^{[25-27]}$ 。相关研究监测表明, 1980-2015 年以来粤港澳大湾区滩涂湿地面积减少了 $582.49 \mathrm{~km}^{2[28]}$ 。 四是生物资源退化, 海岸带生态环境的破坏对红树林、珊瑚礁、海草床等生态系统造成不可逆转的破坏,使防 浪护堤的天然屏障遭到破坏, 天然红树林面积锐减, 严重破坏了浮游生物、鱼虾蟹类、底栖生物和潮间带生物 的生存环境,使生物资源减少 ${ }^{[29-32]}$ 。

\section{2 粤港澳大湾区海岸带生态修复实践及存在的问题}

\section{1 粤港澳大湾区海岸带生态修复实践}

党的十九大提出了“坚持陆海统筹,加快建设海洋强国” 的重要部署, 且广东省也提出了全面建设海洋强 省,加快推进“山水林田湖草 (海)” 等自然资源统一管理和海洋生态保护修复, 严守海洋生态红线, 积极探索 海岸带生态修复有效模式。为深人贯彻落实习近平生态文明思想和自然资源部关于海岸带自然资源、生态保 护修复工作部署, 粤港澳大湾区各沿海城市也都相继开展了一系列的海岸带生态系统修复工程 ${ }^{[33-38]}$ 。总体 来看,粤港澳大湾区已开展的海岸带生态修复工程多以污染治理、河口海岸修复、红树林保护修复、珊瑚礁修 复、生态公园建设为核心。

\section{2 粤港澳大湾区海岸带生态修复存在的主要问题}

由于人为因素和自然因素的影响, 目前粤港澳大湾区海岸带生态系统存在大量的生态环境问题。虽然, 粤港澳大湾区已开展大量海岸带生态系统修复工作,但在进行海岸带生态修复过程中也存在以下六个方面的 问题:一是修复工程总体规划统筹亟待加强。地理边界的连接、生态系统的整体性和环境影响的关联性,决定 了湾区生态环境必须作为一个共同体来统筹考虑。由于我国现行管理机制的条块分割, 粤港澳大湾区具有 “一国两制三法域” 的特殊背景, 大湾区内各城市之间资源要素流动和相互协作较为不足,进而导致各地环境 治理必备的资源和信息未实现互通共享,各地区、各尺度的海岸带生态修复规划、目标、标准等难以统一,继而 导致跨界水污染治理、近岸海域保护等跨行政区环境问题改善效果差强人意 ${ }^{[39]}$ 。二是资源要素协调修复思 维有待加强,各地区对山水林河湖草海生命共同体的认识不到位、需处理的问题不明确,依旧采用传统的思维 模式, 对生态系统中每项要素之间的关系及作用规律综合考虑有限, 大型项目实施效果良莠不齐 ${ }^{[40]}$ 。三是海 岸带修复技术水平有待提高, 从整体上看, 我国海岸带生态修复技术还比较粗放,为快速获取修复成效而忽略 了自然修复的需求 ${ }^{[41]}$ 。四是海岸带生态环境全面评估能力不足,大湾区内自然岸线的不合理占用、典型生态 系统的破坏、陆源污染物乱排放、非法围填海等现象时有发生,有关问题尚未完全登记造册。五是区域性长效 监测机制尚未建立, 大多数工程案例并未开展生态绩效评估, 且相关部门对此缺乏重视, 导致现有生态修复中 常缺失这一部分工作, 使得项目的修复效果难以持续追踪, 无从判断项目是否成功, 更无法为海岸带生态修复 工程提供项目成败的经验及科学的指导 ${ }^{[42]}$ 。六是修复资金和后期维护资金不足,香港、澳门和珠三角九市的 经济体制有极大差异,生态修复资金过度依赖财政资金 ${ }^{[43]}$,难以保证海岸带生态修复工程的持续性。

\section{3 粤港澳大湾区海岸带生态系统修复框架指标研究}

\section{1 粤港澳大湾区海岸带生态系统修复框架}

基于韧性理念的脆弱性和生态系统服务评价可作为海岸带生态保护和修复工作的基础工具和方法 ${ }^{[44]}$; 陆海统筹是海岸带修复框架设计的核心理念 ${ }^{[45]}$; 国土空间生态修复是对生态修复的继承与发展, 更融人生态 系统服务, 而海岸带则是国土空间的重要组成部分 ${ }^{[46-47]}$ 。因此, 在进行粤港澳大湾区海岸带生态系统修复规 
划时,将山水林田湖草 (海)生命共同体理念、韧性理念、陆海统筹理念及国土空间生态修复贯穿到整个规划 中(图 2)。按照国土空间生态修复的规则, 以"整体谋划, 分区、分类、分级施策" 为原则,构建由珠三角核心 区、粤港澳大湾区、珠三角城市群、珠江流域构成的 “一核一区一群一流域” 区域生态修复规划新格局。从粤 港澳大湾区生态系统整体性和系统性人手,识别粤港澳大湾区突出的跨区域的共性生态环境问题; 以全面协 调为导向,构建 “一国两制” 框架下的跨区域生态保护和修复协同联动机制。分析整个湾区海岸带与海岛开 发与保护的现状特征与存在问题,识别海岸带与海岛修复的重要任务与重点地段。构建粤港澳大湾区海岸带 生态保护与修复总体格局, 明确生态修复的目标、指标和任务, 按照自然修复为主、人工修复为辅的生态修复 策略,进行海岸带生态系统修复。

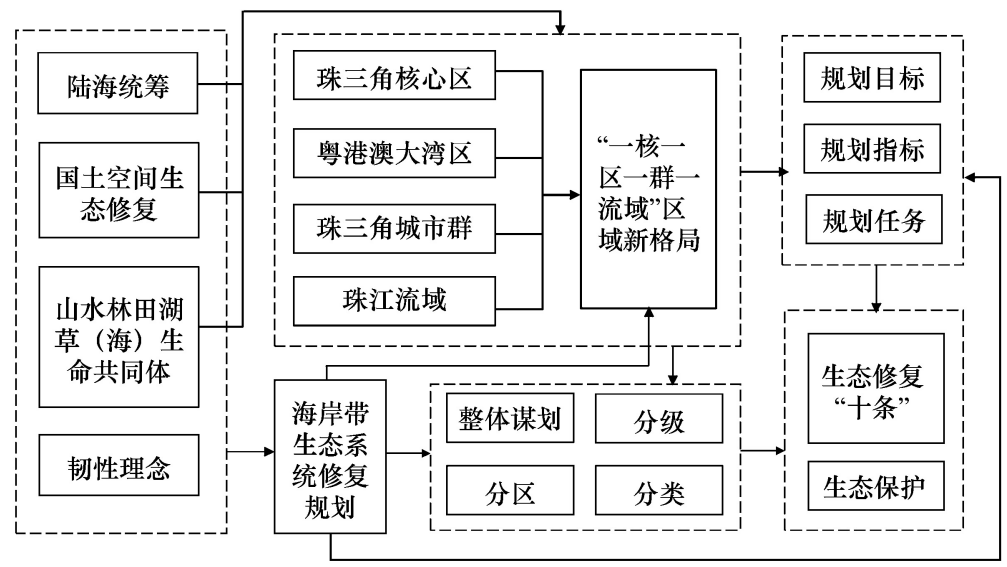

图 2 盻港澳大湾区海岸带生态系统修复框架图

Fig.2 Decision-making processes of coastal ecosystem restoration in the Guangdong-Hong Kong-Macao Greater Bay Area

\section{2 粤港澳大湾区海岸带生态系统修复目标设计}

以习近平新时代中国特色社会主义思想为指导, 深人贯彻落实习近平生态文明思想和自然资源部关于海 岸带自然资源、生态保护修复工作部署,遵循“山水林田湖草(海) 是一个生命共同体” 的理念, 坚持保护优先、 自然恢复为主的方针,积极响应落实《广东省国土空间生态修复规划 ( 2020-2035 年)》和《粤港澳大湾区发 展规划纲要》,开展粤港澳大湾区“一核一区一群一流域” 区域生态修复规划新格局,进行粤港澳大湾区海岸 带生态系统修复。按照整体谋划, 分区、分类、分级修复的思路, 科学确立海岸带生态系统修复目标体系和主 要任务, 有序部署海岸带生态系统修复重大重点工程, 推动形成奥港澳大湾区海岸带生态系统的生态修复新 机制, 实现 “水清、岸绿、滩净、湾美、岛丽” 的粤港澳大湾区海岸带生态系统修复规划新目标, 优化湾区的海岸 带生态环境, 维护湾区的海岸带生态平衡, 提高湾区的海岸带生态安全格局, 促进粤港澳大湾区的可持续发展 和生态文明建设。

\section{3 粤港澳大湾区海岸带生态系统修复指标设计}

在进行粤港澳大湾区海岸带生态系统修复规划指标设计时, 主要根据粤港澳大湾区海岸带现存的生态环 境问题和海岸带生态系统修复目标进行确定, 主要包含为自然岸线保有率、近岸海域水质质量、海岸侵蚀状 况、滨海湿地 (滩涂) 环境 (湿地数量、湿地结构以及湿地生态功能)、渔业资源状况、红树林面积、珊瑚礁面积、 海草床面积、砂质岸线长度、海岛数量及环境状况。

\section{4 粵港澳大湾区海岸带生态系统修复若干关键点}

《中共中央、国务院关于建立国土空间规划体系并监督实施的若干意见》提出“分级分类建立国土空间规 划”, 是统筹和科学推进国土空间生态修复工作的重要引领。在进行粤港澳大湾区海岸带生态系统修复规划 时按照整体谋划,分区、分类、分级施策的方式,构建由珠三角核心区、粤港澳大湾区、珠三角城市群、珠江流域 
构成的“一核一区一群一流域”区域修复规划新格局,提出粤港澳大湾区海岸带生态系统修复“十条”。

\section{1 粤港澳大湾区海岸带生态系统修复分区}

根据生态环境敏感性、生态服务功能重要性和区域社会经济发展差异性等,将粤港澳大湾区海岸带影响 范围划分为珠三角核心区、粤港澳大湾区、粤港澳大湾区海岸带辐射区 (图 3)。珠三角核心区是推动粤港澳 大湾区海岸带生态系统修复规划的核心区和主引擎,以广州、深圳、香港、澳门“四核”为重点城市。粤港澳大 湾区是开展粤港澳大湾区海岸带生态系统修复规划的关键, 按照空间格局和生态环境的相对一致性,将粤港 澳大湾区海岸带划分为大亚湾区、珠江口区、大广海湾区、香港海区和澳门海区五大典型湾区; 按照地理位置, 将粤港澳大湾区海岸带分为滨海区 (珠三角沿海七市、港澳)和近海区 (肇庆、佛山)。粤港澳大湾区海岸带辐 射区的中心区域珠三角城市群, 是完成奥港澳大湾区海岸带生态系统修复规划的支撑, 以珠江流域为媒介, 形 成陆海统筹、山水林田湖草(海)生命共同体的的海岸带修复规划策略。

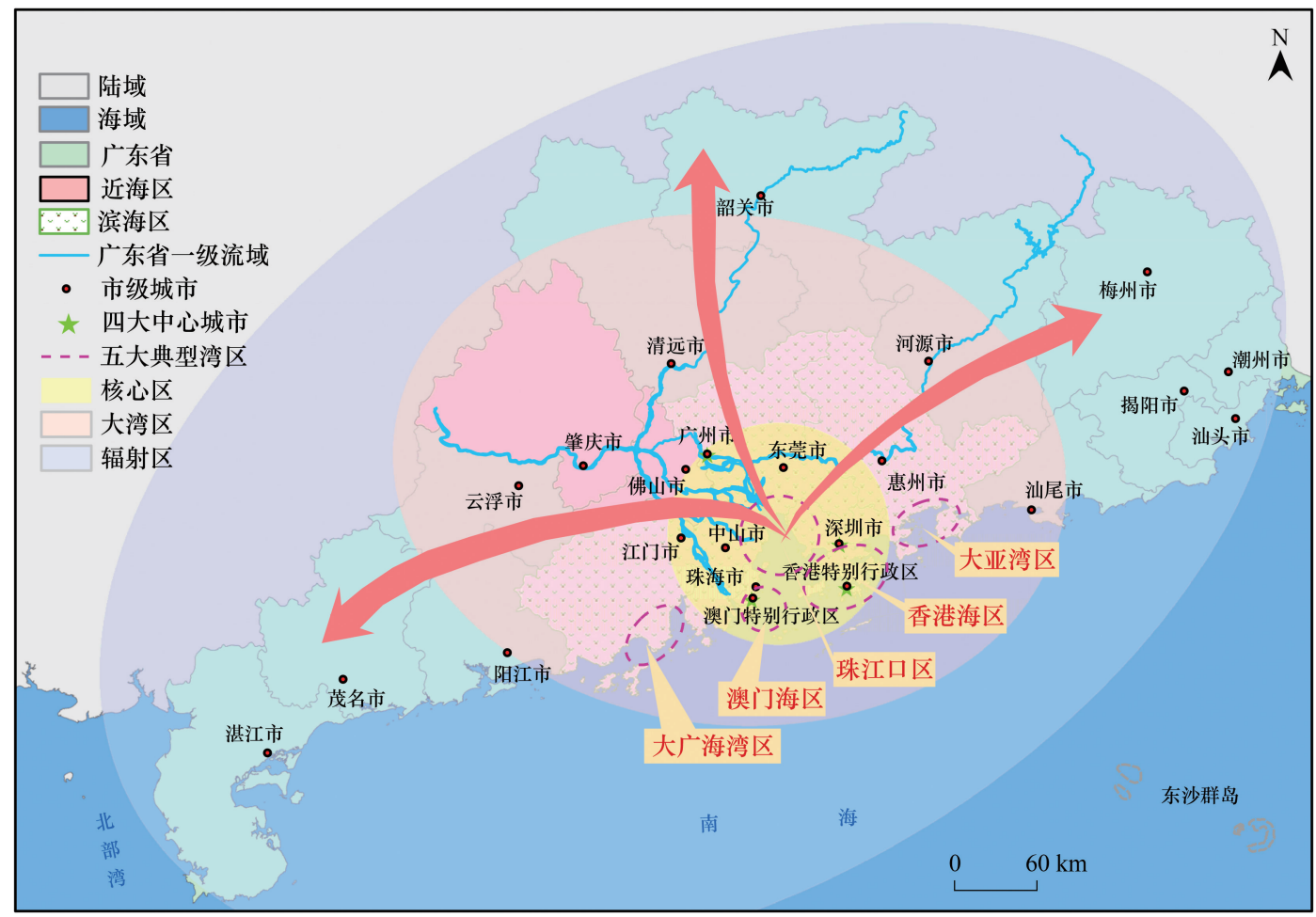

图 3 粵港澳大湾区海岸带生态系统修复分区图

Fig.3 Division of coastal ecosystem restoration in the Guangdong-Hong Kong-Macao Greater Bay Area

4.2 粤港澳大湾区海岸带生态系统修复分类

海岸带生态系统不仅是处于陆域与浅海交界区域,一种过渡型的生态系统,而且是陆地、海洋、大气间相 互作用最活跃的地带 ${ }^{[48]}$ 。海岸带生态系统包含有多种类型,典型的有红楖林、珊瑚礁、海草、沙滩、盐沼、潟湖 和河口等多种生态系统 ${ }^{[49]}$ 。在进行粤港澳大湾区海岸带生态系统修复分类规划时, 根据海岸带生态系统的 类型,分别开展粤港澳大湾区红树林生态系统修复、海岛生态系统修复、河口生态系统修复、珊瑚礁生态系统 修复 (图 4)。采取陆海统筹思维、国土空间生态修复方法,制定粤港澳大湾区海岸带生态保护修复与合理利 用规划, 优化海岸开发利用布局,加强区域之间、陆海之间的联防联治, 全覆盖多举措统筹生态修复任务,开展 粤港澳大湾区重点海湾、自然保护区的核心区及缓冲区、海洋特别保护区的重点保护区及预留区、重点河口区 域、重要滨海湿地区域、重要砂质岸线及沙源保护海域、特殊保护海岛及重要渔业海域等重点保护区域的岸线 管理。 


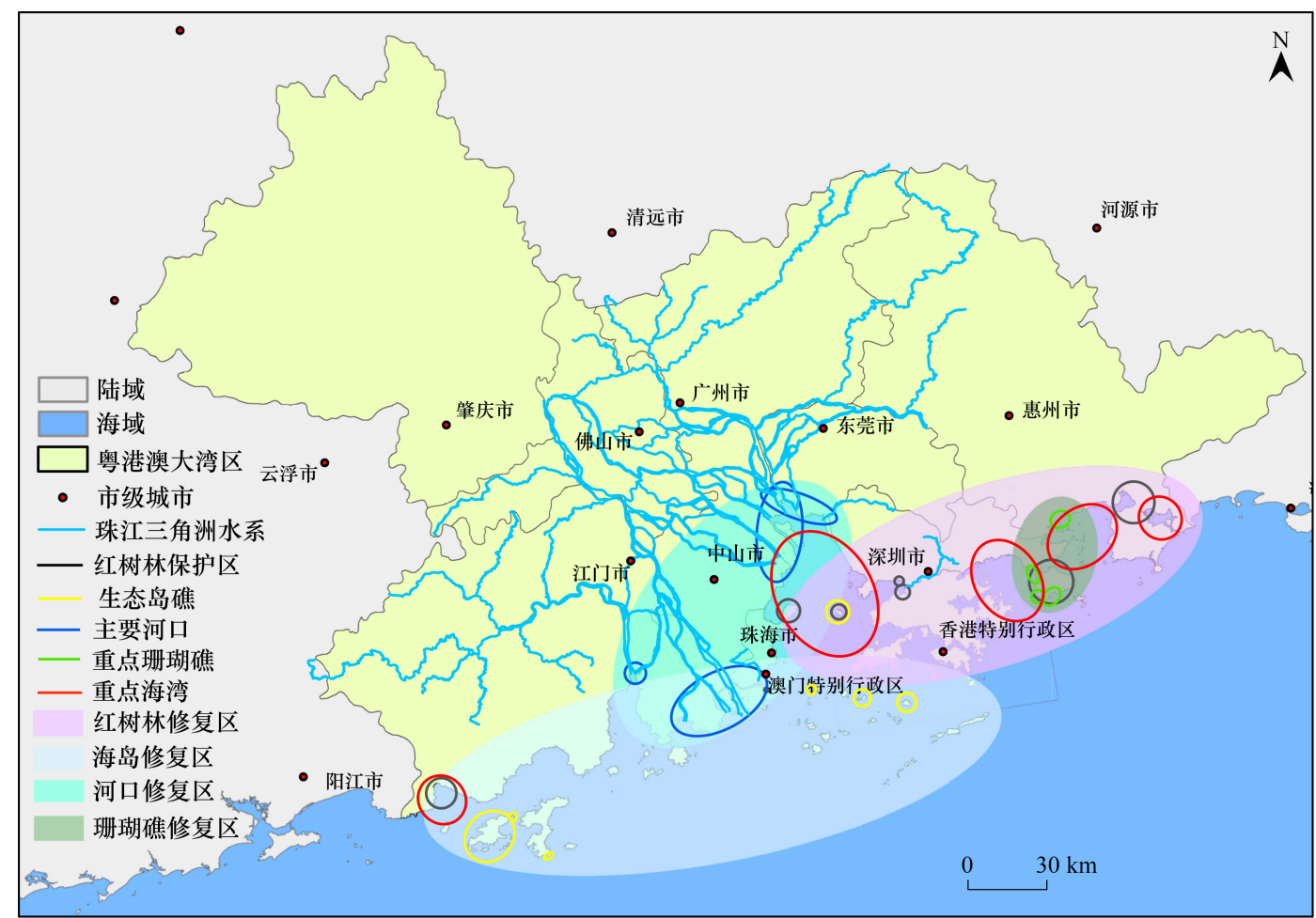

图 4 棞港澳大湾区海岸带生态系统修复分类图

Fig.4 Classification of coastal ecosystem restoration in the Guangdong-Hong Kong-Macao Greater Bay Area

\section{3 粤港澳大湾区海岸带生态系统修复分级}

根据海岸带生态系统的重要性、敏感性、脆弱性,参照《广东省海洋生态红线》对于大陆自然岸线保有率、 海岛自然岸线保有率、近岸海域水质优良 (一、二类) 比例等控制指标的划定以及广东省生态功能区划、广东 省海洋功能区划、广东省主体功能区划, 在进行粤港澳大湾区海岸带生态系统修复分级规划时, 将海岸带生态 系统划分为一级重要生态功能区保护、二级生态脆弱区或敏感区保护、三级生物多样性保护,实行海岸带生态 系统分级管控 (图 5)。一级重要生态功能区保护包含重点海湾、红树林、海岛、河口、珊瑚礁等重要生态系统 修复区, 重点开展海岸带生态修复工程, 维护海岸带生态安全。二级生态脆弱区或敏感区保护以珠江口为核 心, 将影响河口生态系统生态环境及生态平衡的区域划定为脆弱区或敏感区, 以河口为重点, 坚持水陆联动、 陆海统筹, 明确水生态空间修复重点区域。三级生物多样性保护是以流域为载体, 将影响海岸带生态系统生 态环境的粤港澳大湾区诸多小流域划分为生物多样性保护,该区域以生物多样性保护与水源涵养为重点, 分 区开展生物多样性修复与保护。

4.4 以流域为单元的粤港澳大湾区海岸带生态系统修复

珠江口是三角洲网河和残留河口湾并存的河口; 河口区河汉发育,水网密布。珠江流域广东省部分主要 由西江水系、珠江三角洲水系、北江水系、东江水系、韩江水系、广东沿海诸河水系等众多水系构成。因此,在 进行粤港澳大湾区海岸带生态系统修复时, 根据水系的分布及流向, 将其划分为粤西沿海流域、西江流域、珠 江三角洲流域、北江流域、东江流域、粤东沿海流域 (图 6), 并将其作为生态修复治理的基本单元 ${ }^{[50]}$, 从生态 系统整体性和流域系统性出发, 实施以水为核心的山水林田湖草 (海)一体化修复, 坚持水陆联动、陆海统筹, 明确水生态空间修复重点区域, 将河岸与海岸带作为水陆联通、陆海交会两大重要交界带, 有针对性地提出生 物、物理、化学和综合政策等修复策略。

4.5 粤港澳大湾区海岸带生态系统修复“十条”

借鉴我国“水十条”、“气十条”、“十条”的实施策略及其成效, 提出粤港澳大湾区海岸带生态系统修复 


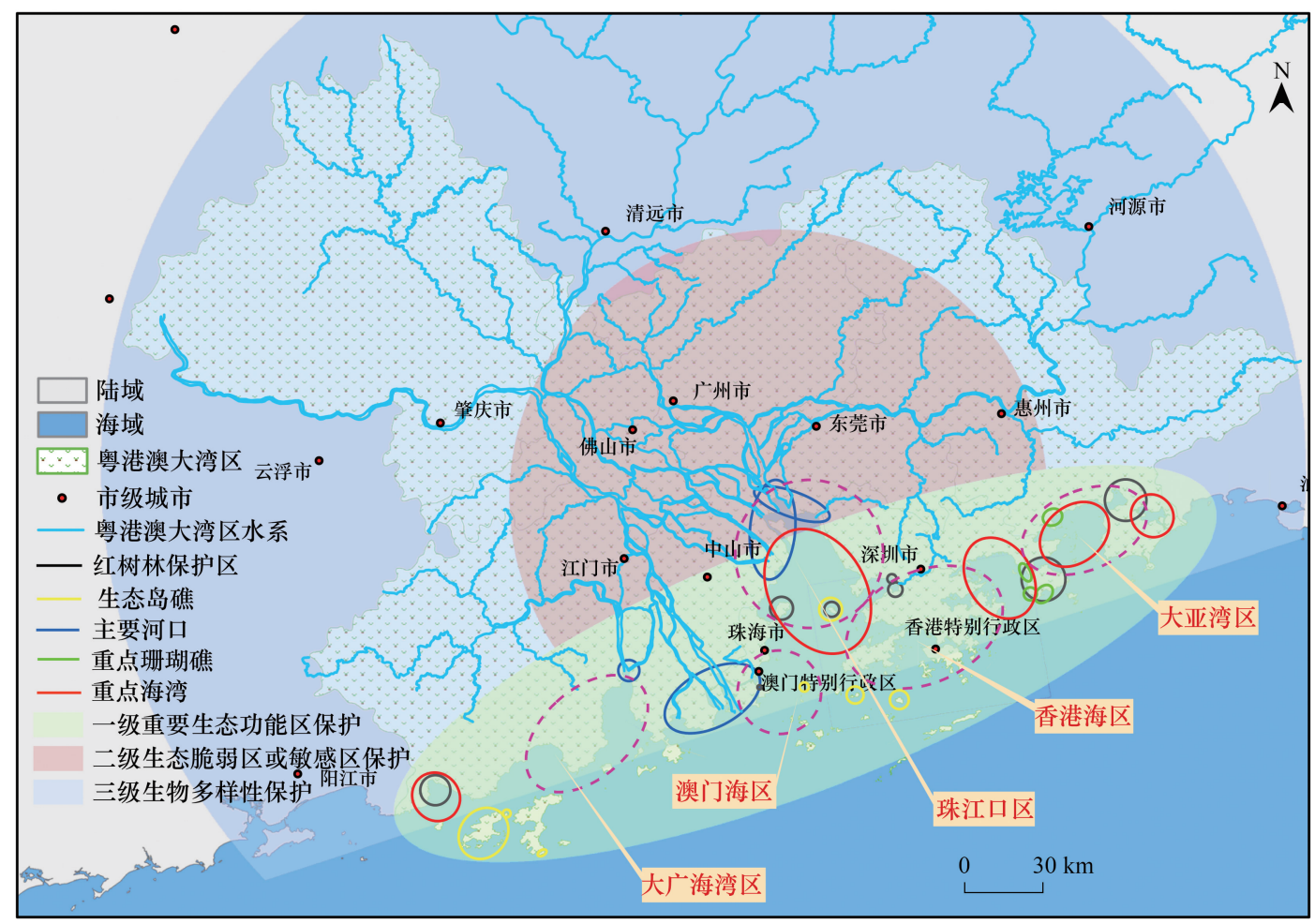

图 5 粤港澳大湾区海岸带生态系统修复分级图

Fig.5 Categorization of coastal ecosystem restoration in the Guangdong-Hong Kong-Macao Greater Bay Area

十条,包括: (1) 建立粤港澳大湾区国土空间数据信息综合管理平台,全面管控奥港澳大湾区海岸带生产、生 活和生态空间; (2) 系统开展粤港澳大湾区海岸带调查评估,强化自然岸线及其自然资源全面保护; (3) 加强 粤港澳大湾区海岸带污染管控和环境综合整治,建设蓝色海湾; (4) 优化粤港澳大湾区海岸带产业结构,强化 产业生态化改造; (5) 实施重点示范工程, 大力推动海岸带生态系统修复; (6) 编制生态产业化方案, 创新海岸 带生态修复增值模式; (7) 推进海岸带评价考核与监管,探索建立粤港澳大湾区海岸带管理立法; (8)强化海 岸带与东江、西江及珠三角河网的联系,统筹广东与香港、澳门海域海岛的协调管理,构建系统综合、陆海统筹 的生态安全体系; (9) 开展海岸带生态修复技术研发与科技攻关, 实施海岸带生态修复效益评价, 强化技术体 系标准化建设; (10)引人激励机制和社会资本, 建立社会监督开放平台, 构建海岸带生态修复多元化保障 机制。

\section{5 结论与建议}

本文通过分析粤港澳大湾区海岸带基本特征和粤港澳大湾区海岸带生态修复实践及存在的问题,提出了 以下粤港澳大湾区海岸带生态系统修复思路: (1) 将山水林田湖草(海)生命共同体理念、韧性理念、陆海统筹 理念及国土空间生态修复贯穿到修复建设,进行粤港澳大湾区海岸带生态系统修复分区、分类、分级的框架构 建。(2)构建由珠三角核心区、粤港澳大湾区、珠三角城市群、珠江流域构成的粤港澳大湾区 “一核一区一群 一流域” 的海岸带生态系统修复新格局。(3) 将流域作为生态修复治理的基本单元, 从生态系统整体性和流 域系统性出发, 坚持水陆联动、陆海统筹, 有针对性地提出修复策略。(4) 以生态修复为基础, 提出粤港澳大 湾区海岸带生态系统修复“十条”。

建议根据在今后的修复实践中,参考奥港澳大湾区“一核一区一群一流域” 的海岸带生态系统修复新格 局, 逐一进行粤港澳大湾区海岸带生态系统修复策略探索研究。此外, 在未来粤港澳大湾区海岸带生态修复 设计中,建议结合生态保护红线、环境质量底线、资源利用上线三条红线,以及生态功能分区规划、社会经济发 


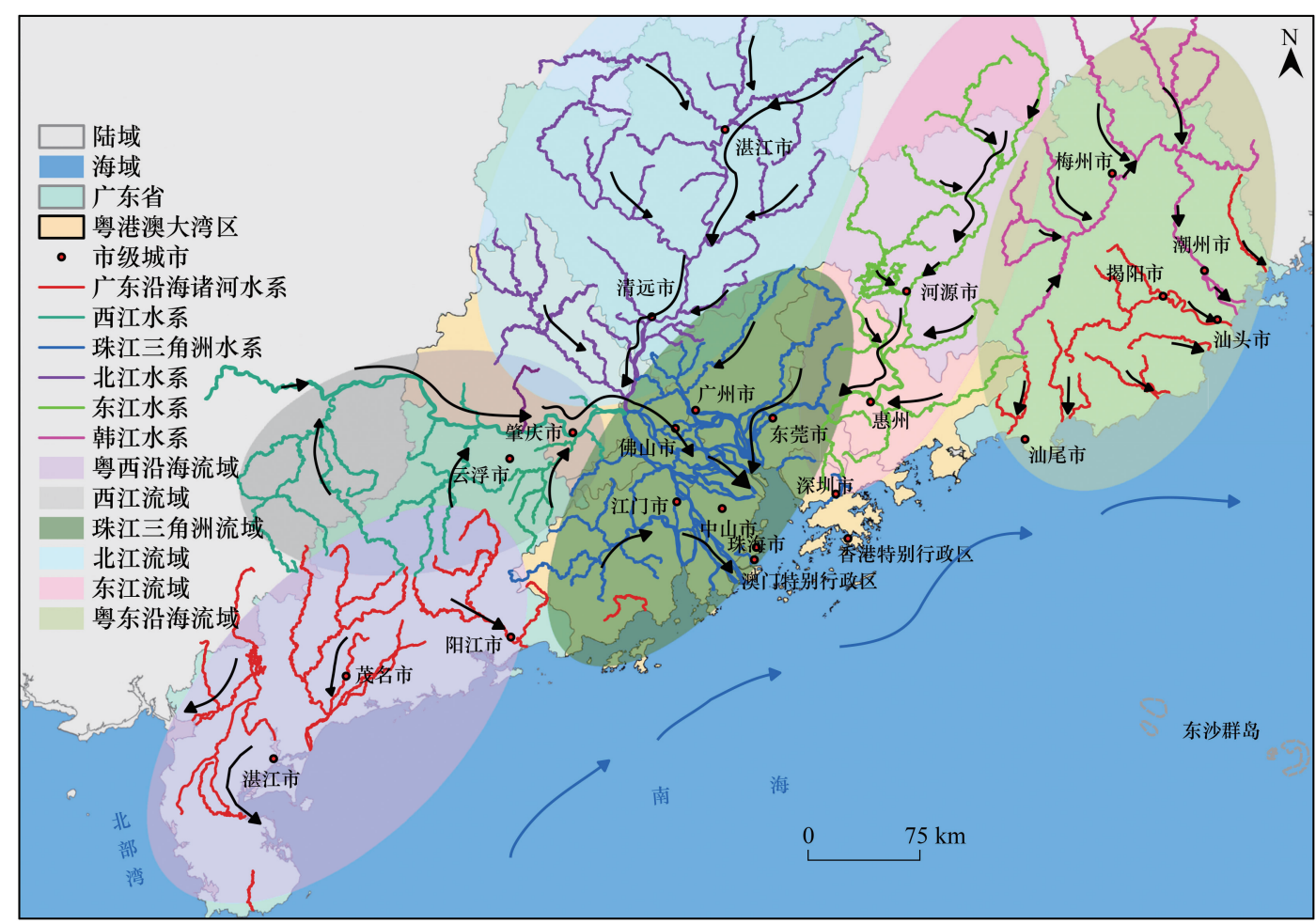

图 6 基于流域为单元的粤港澳大湾区海岸带生态系统修复图

Fig.6 Coastal ecosystem restoration in the Guangdong-Hong Kong-Macao Greater Bay Area based on watershed distribution

展规划等顶层设计,有效提升海岸带修复规划分区、分类、分级的科学性和可行性,避免多种规划之间产生矛 盾。此外,还应针对海岸带生态修复工程进行风险评估和管控,制定应对策略,确保陆海统筹系统下的生态安 全得以实现。

\section{参考文献 (References) :}

［1］国务院办公厅. 中共中央 国务院印发《粤港澳大湾区发展规划纲要》. (2019-02-18). http://www.gov.cn/zhengce/2019-02/18/content_ 5366593.htm\#1.

[ 2 ] 赵蒙蒙, 寇杰锋, 杨静, 赵文静. 粤港澳大湾区海岸带生态安全问题与保护建议. 环境保护, 2019, 47(23) : 29-34.

[ 3 ] 范丹, 王明旭. 国际三大湾区环境保护对粤港澳大湾区的经验启示. 环境科学与管理, 2019, 44(4): 13-16.

～４］唐迎迎，高瑜，冊瑾超，任海波，金信飞. 海岸带生境破坏影响因素及整治修复策略研究. 海洋开发与管理, 2018, 35(9) : 57-61.

[ 5 ] Yanes A, Botero C M, Arrizabalaga M, Vásquez J G. Methodological proposal for ecological risk assessment of the coastal zone of Antioquia, Colombia. Ecological Engineering, 2019, 130: 242-251.

[ 6 ] Zhai T L, Wang J, Fang Y, Qin Y, Huang L Y, Chen Y. Assessing ecological risks caused by human activities in rapid urbanization coastal areas: towards an integrated approach to determining key areas of terrestrial-oceanic ecosystems preservation and restoration. Science of the Total Environment, 2020, 708: 135153.1-135153.14.

[ 7 ] Sadio M, Anthony E J, Diaw A T, Dussouillez P, Fleury J T, Kane A, Almar R, Kestenare E. Shoreline changes on the wave-influenced Senegal river delta, west Africa: the roles of natural processes and human interventions. Water, 2017, 9(5): 357.

[ 8 ] He Q, Bertness M D, Bruno J F, Li B, Chen G Q, Coverdale T C, Altieri A H, Bai J H, Sun T, Pennings S C, Liu J G, Ehrlich P R, Cui B S. Economic development and coastal ecosystem change in China. Scientific Reports, 2014, 4: 5995.

[ 9 ] Pejchar L, Mooney H A. Invasive species, ecosystem services and human well-being. Trends in Ecology \& Evolution, 2009, 24(9) : 497-504.

[10］梁雄伟. 基于自然资源统一管理的广东省海岸带生态修复. 海洋开发与管理, 2019, 36(6) : 33-38.

[11］孙杰, 詹文欢, 姚衍桃, 刘守金, 冯英辞. 广东省海岸侵蚀现状及影响因素分析. 海洋学报, 2015, 37(7): 142- 152.

[12] Cao W Z, Wong M H. Current status of coastal zone issues and management in China: a review. Environment International, 2007, 33(7) : 985-992.

[13] 朱晓东, 施丙文. 海岸带环境管理与评价的基本问题. 海洋开发与管理, 1998, 15(2): 28-31. 
[14] 战祥伦. 基于生态系统方式的海岸带综合管理研究 $[D]$. 青岛: 中国海洋大学, 2006.

［15］＼cjkstart唐玲, 杨木壮，王银霞，高杨，田松，董迪. 粤港澳大湾区海岛空间分布特征探析. 海洋学研究，2020, 38(2) : 74-80.

［16］赵玉灵. 奥港澳大湾区自然资源遥感调查与保护建议. 国土资源遥感, 2018, 30(4) : 139-147.

[17] Kennedy D M, Sherker S, Brighton B, Weir A, Woodroffe C D. Rocky coast hazards and public safety : moving beyond the beach in coastal risk management. Ocean \& Coastal Management, 2013, 82: 85-94.

[18] 洪义国, 徐杰, 岳维忠, 吴梅林, 施震, 孙毓金, 吴佳鹏, 王岩, 汪光, 陈中颢, 刘晓伟. 珠江广州河段-珠江口活性氮 ( Nr) 污染的源汇过 程及其对区域水体生态安全的影响. 广东省, 中国科学院南海海洋研究所, 2018-11-14.

[19] Tian B, Wu W T, Yang Z Q, Zhou Y X. Drivers, trends, and potential impacts of long-term coastal reclamation in China from 1985 to 2010. Estuarine, Coastal and Shelf Science, 2016, 170: 83-90.

[20] Grenfell S E, Callaway R M, Grenfell M C, Bertelli C M, Mendzil A F, Tew I. Will a rising sea sink some estuarine wetland ecosystems?. Science of the Total Environment, 2016, 554-555: 276-292.

[21］张怡. 近 40 年来珠江口海岸线变迁遥感分析 [D ]. 呼和浩特: 内蒙古师范大学, 2014.

[22］易斌，陈凯彪，周俊杰，吕意华. 2009 年至 2016 年华南近海赤潮分布特征. 海洋湖沼通报, 2018, (2) : 23-31.

[23] Xie Y J, Yu X J, Ng N C, Li K, Fang L. Exploring the dynamic correlation of landscape composition and habitat fragmentation with surface water quality in the Shenzhen river and deep bay cross-border watershed, China. Ecological Indicators, 2018, 90: 231-246.

[24] 覃超梅, 于锡军. 海平面上升对广东近岸海域环境影响研究. 环境科学与管理, 2012, 37(8): 37-38, 61-61.

[25] Schernewski G, Schumacher J, Weisner E, Donges L. A combined coastal protection, realignment and wetland restoration scheme in the southern Baltic: planning process, public information and participation. Journal of Coastal Conservation, 2018, 22(3) : 533-547.

[26] Jiang T T, Pan J F, Pu X M, Wang B, Pan J J. Current status of coastal wetlands in China: degradation, restoration, and future management. Estuarine, Coastal and Shelf Science, 2015, 164: 265-275.

[27] An S Q, Li H, Guan B H, Zhou C F, Wang Z S, Deng Z F, Zhi Y B, Liu Y H, Xu C, Fang S B, Jiang J H, Li H L. China's natural wetlands: past problems, current status, and future challenges. AMBIO: A Journal of the Human Environment, 2007, 36(4) : 335-342.

[28] 崔保山, 谢活, 王青, 李姗泽, 闰家国, 于淑玲, 刘康, 郑京晶, 刘泽正. 大规模围填海对滨海湿地的影响与对策. 中国科学院院刊, 2017, 32(4) : 418-425.

[29] Chang Y, Chen Y N, Wang Y P. Field measurements of tidal flows affected by mangrove seedlings in a restored mangrove swamp, Southern China. Estuarine, Coastal and Shelf Science, 2020, 235: 106561

[30］潘澎, 赖子尼. 生活污水对珠江口渔业水域环境的影响评价. 海洋渔业, 2016, 38(6): 616-622.

［31］赵玉灵. 珠江口地区近 30 年海岸线与红树林湿地遥感动态监测. 国土资源遥感, 2010, (S1) : 178-184.

[32] 施蕴文. 广东省珊瑚礁生态保护对策研究 [D]. 湛江: 广东海洋大学, 2018.

[33] 张大达, 陈本亮, 冯永军. 广州海珠国家湿地公园生态恢复技术初探. 湿地科学与管理, 2016, 12(4): 39-41.

[34] 杨洪, 刘家宝, 黄鹄, 任海, 宁天竹, 徐华林, 蔡毅, 郑道才, 孙秀波, 黄东佳, 廖琦, 景艳波, 李瑞成, 张妙辉, 邹淑坤. 深圳福田凤塘 河口湿地生态系统修复研究与示范. 广东省, 深圳市福田区生态建设办公室, 2012-11-08.

[35］廖静，管丽娟，欧阳勇. 深圳华侨城湿地一一再造“鸟的天堂”. 海洋与渔业, 2018, (4)：36-38.

[36] 张妍, 陈佳荣, 魏晓. 全国首个以珊瑚礁生态养护为主的国家级海洋牧场|将为海洋生态资源人工修复探索经验. (2019-01-16). https:// www.sohu.com/a/289544180_726570.

[37] 张留恩, 廖宝文. 珠海市淇澳岛红树林湿地的研究进展与展望. 生态科学, 2011, 30(1) : 81-87.

[38］香港特别行政区政府环境保护署. 净化海港计划. (2020-02-24). https://www.epd.gov.hk/epd/sc_chi/environmentinhk/water/cleanharbour/ home.html.

[39］许堞，马丽. 粤港澳大湾区环境协同治理制约因素与推进路径. 地理研究, 2020, 39(9) : 2165-2175.

[40］王晶. 论国土空间生态修复工程的问题与技术创新. 科学与信息化, 2019, (4) : 185- 186.

[41] 盛晓琼, 齐良富, 王晓玲, 罗晓波. 广东海珠国家湿地公园植物资源现状与优化策略研究. 四川林勘设计, 2016, (1): 42-45.

[42] 吴威, 李彩霞, 陈雪初. 基于生态系统服务的海岸带生态修复工程成效评估一以鹦怔洲湿地为例. 华东师范大学学报: 自然科学版, 2020, (3) : 98-108.

[43] 刘影, 林韶. 生态环境修复资金管理探析. 市场论坛, 2019, (10) : 46-48.

［44］李杨帆, 向枝远, 杨奕, 王泉力, 李艺. 基于韧性理念的海岸带生态修复规划方法及应用. 自然资源学报, 2020, 35(1)：130-140.

[45] 安太天, 朱庆林, 武文, 岳奇, 刘林哲, 刘若晗, 史亚平. 基于陆海统筹的海岸带国土空间规划研究. 海洋经济, 2020, 10(2): 44-51.

[46］高世昌. 国土空间生态修复的理论与方法. 中国土地, 2018, (12) : 40-43.

[47] 俞孔坚. 基于自然, 让自然做功一一国土空间规划与生态修复之本. 景观设计学, 2020, 8(1): 6-9.

[48] 刘㻦, 马龙, 李颖, 杨洋. 海岸带生态系统及其主要研究内容. 海洋环境科学, 2008, 27( 5) : 520-522.

［49］孟伟庆, 胡蓓蓓, 刘百桥, 周俊. 基于生态系统的海洋管理一一概念、原则、框架与实践途径. 地球科学进展, 2016, 31(5)：461-470.

[50］姜良勇, 李继清, 陈思雨. 珠江流域水资源调度大数据指标体系构建. 人民珠江, 2020, 41 (5)：108-115. 